\title{
Strategic cost management, contingent factors and performance in services
}

\author{
Odysseas Pavlatos ${ }^{a, 1}$ \\ ${ }^{a}$ Athens University of Economics and Business, Greece
}

\begin{abstract}
A bstract: The purpose of this paper is to investigate the relationship between contextual factors identified from contingency-based research, the extent of the use of strategic cost management (SCM) techniques and business performance in services. An empirical survey was conducted on a sample of 88 services in Greece. The analysis of the survey data indicates that the use of strategic cost management techniques in services can be considered quite satisfactory. By drawing on the grounds of contingency theory, five factors were identified as potentially exhibiting an emergent relationship with strategic cost management The five factors are; (1) Perceived environmental uncertainty, (2) Structure, (3) Organizational life cycle stage, (4) Strategy and (5) Size. The survey reved ed that SCM usage is positively affected by these five contingent factors, while SCM usage, in turn, positively affects performance A significant mediating effect of SCM usage on performance is evident.
\end{abstract}

K eywords: strategic cost management, contingent factors, performance, services, Greece

\section{J EL codes: M41}

${ }^{1}$ Corresponding authors: Department of Business Administration, Athens University of Economics and Business, Aminiou Str. 3, 1163 Athens; tel. (+30) 6944362919; email addresses: opaulatos@gmail.com 


\section{Introduction}

In the recent literature has presented many innovative management accounting tools, such as strategic cost management tools (Abdel-Kader \& Luther, 2008; Zawawi \& Hoque, 2010).

As a matter of fact, the last few years have seen a growing interest in Strategic Cost Management (SCM) despite the considerable discourse on strategic cost management that has prevailed since the early 1980s (Bromwich, 1990; Roslender \& Hart, 2003). Nevertheless, very little has been achieved in terms of empirical enquiry designed to further our appreciation of the nature and the context of SCM application (Cadez \& Guilding, 2008). However, there ought to be further research that is geared towards developing the test hypotheses on factors that relate to SCM adoption and usage.

Chenhall (2003) reports that there is a need for more research into service organizations on management accounting system design and contextual variables since these entities become increasingly important within most economies. More recently, Chenhall and Moers (2015) report little management accounting system design work considering innovative tools, in services. The role of management accounting system related to service areas offer many opportunities to research (Chenhall \& Moers, 2015).

Existing research in service organizations tends to focus on organizations in one industry (e.g. health care industry, communication industry, banking industry, hospitality industry) or in a single organization, or focusses on not- for profit organizations (Auzair, 2015). As services range across retail, health care, education, hospitality and professional services, limited generalizations can be drawn from such a narrow focus (Auzair, 2015).

Performance management literature suggests that there is a relationship betwen performance management system design and previous performance in services (Naranjo-Gil et al., 2009). The historical performance of an organization is another factor that might influence the need to adopt innovative management accounting tools (Naranjo-Gil et al., 2009). Firms which have performed relatively badly over the previous period will experience a relatively high, and perhaps urgent, need to change their systems, as has been widely recognized in the general management literature (e.g. Pavlatos, 2015). Previous research has explored the impact of historical performance and firm characteristics (direct and interaction effects) on strategic cost management usage (e.g. Pavlatos, 2015).

Instead, this research explores how contingencies affect business performance through strategic cost management adoption and usage (indirect effects). This study examines the effect of contingent factors on strategic cost management and, 
in turn, the mediating effect of SCM on company performance. This paper explores the effect of using strategic cost management tools on business performance, which has not been explored, as far as we know, in the service sector (Chenhall \& Moers, 2015).

The present study contributes to the literature on organizational configurations in particular by examining the systematic nature of effective service organizations when adapting to their contextual settings. The findings provide support for contingency theory's central proposition that organizational performance depends on the fit between organizational context and structure in a service context This research concludes that the application of SCM systems are not necessarily related to superior performance, but that superior performance is a product of an appropriate match between contingent factors and SCM application.

The remainder of the paper is structured as follows. The next section provides a synthesis of the most pertinent literature Hypotheses are then developed concerning factors that might impact upon the usage rates SCM. This is followed by an analysis of the research methodology and thereafter the survey results. Conclusions, limitations and implications for future research are presented in the final section.

\section{Theory and hypothesis development}

"The increasing research on strategic cost management or strategic management accounting is as a result of its increasing importance to managers of information from all boundaries of the firm" (Simmonds, 1981, p.360). It was in fact pointed out that the external focus of SCM and further research has been consistent with their premise (Cinquini \& Tenucci, 2010).

To help in the progress, Guilding et al. (2000) provided an original distillation of SCM techniques as well as criteria for viewing a particular accounting technique as "strategic". They further drew 12 SCM techniques from the literature. Furthermore, Cravens and Guilding (2001) added another three techniques and finally, 16 SCM techniques have been identified by Cadez and Guilding, (2008). There are an evident number of surveys of SCM practice that have been carried out (Carr et al., 1991; Carr \& Tomkins, 1996, 1998; Guilding \& al., 2000; Cravens \& Guilding, 2001; Guilding \& McManus, 2002; Cinquini \& Tenucci, 2010). These surveys have found out that competitor focused accounting and strategic pricing are the most widely used techniques. However, some al so suggest that the term SCM is not widely used in companies, and its meaning is not al ways clear to managers (Tillmann \& Goddard, 2008). The above surveys have been conducted only in manufacturing industries. 
The literature search reveals no overdue enquiry on the val idity of viewing SCM as a coherent empirical construct in a service environment. Moreover, no prior empirical work concerned with the application of SCM techniques in a service context has been yet reported.

The contingency theory approach to studying SCM practice is one of the techniques that have been used by most researchers (Simons, 1987; Chenhall \& Langfield-Smith, 1998; Guilding, 1999; Anderson \& Lanen, 1999; Abernethy and Brownell, 1999; Cinquini \& Tenucci, 2010). Otley (2016) reviews the literature on the contingency theory of management accounting since the 1980 . He suggests that the narrow view of contingency that relies on responses to generally applicable questionnaires needs to be replaced by a more tailored approach that takes into account the context of specific firms.

In line with the above, Cadez and Guilding (2008) examined the effect of strategic choices, market orientation, and company size on two distinct dimensions of SCM and the mediating effect of SCM on company performance in a comprehensive contingent model.

This research was based on the framework of Cadez and Guilding (2008), and was expanded on the following: Firstly, this study examined the impact of those contingencies that have not yet been studied. Such contingent factors include; "Perceived environmental uncertainty", "Structure", "and "Organizational life cycle stage" on strategic cost management practices which have not been previously studied. It is for that reason that they have been included in this study.

Furthermore, this research was restricted to including only service organizations. Messner (2016) explained how industry matters of management accounting practice and how this type of context can be accounted for in empirical studies. Prior research regarding the investigation of the factors that influence the use of SCM has been mainly related to large manufacturing companies. In the service sector, Pavlatos (2015) examined the impact of contingent factors on Strategic Management Accounting in the Greek hospitality industry. He found that firms characteristics and specific industry factors affect the use of strategic management accounting tools in a service context.

Moreover Auzair (2015) used a configuration approach to examine the relationships between multiple contingent variables (e.g. strategy, process type, size, organizational lifecycle stage) and management control systems (MCS) in service organizations from various industries. She found that strategic orientation plays an important role in high-performing firms and the ability to incorporate various contingent situations determines the effectiveness of an organization. 


\subsection{Perceived environmental uncertainty (PE U)}

The external environment is a powerful contextual variable that is at the foundation of contingency- based research. Perceived environmental uncertainty (PEU) is defined as a situation where managers perceive elements of the environment to be uncertain, with uncertainty distinguished from risk "as uncertainty defines situations in which probabilities are not attached" (Chenhall, 2003, p. 137). Perceived environmental uncertainty is seen to be an important contextual factor in the design of MCS because increased PEU makes managerial planning and control more difficult (Lawrence \& Lorsch, 1967).

Chenhall and Morris (1986) and Gordon and Narayanan (1984) report that as decision makers perceive greater environmental uncertainty, they tend to seek external, non-financial and ex ante information in addition to other types of information. Gul and Chia (1994) found that when PEU is low, management is able to make relatively accurate predictions about the market, while when PEU is high management may require additional information to cope with complexities of the environment According to Abdel-Kader and Luther (2008) there is positive association between management accounting sophistication and PEU. Gul iding and McManus (2002) found that there is a weak association between customer focused accounting and competition intensity.

Based on these arguments and findings, the perceived environment is likely to play a positive role in affecting the extent to which strategic management accounting practices is used by firms. Firms perceiving a higher degree of environmental uncertainty may use more strategic cost management than firms that perceived lower environmental uncertainty. The intensity of price competition, the economic environment, the legal and political constraints, the market activities of the competitors and the preferences of the customers may affect the extent of the use of SCM.

In the service industries, firms facing relatively high environmental uncertainty may place greater emphasis on SCM to help them to reduce uncertainty and improve managerial decision-making, managerial planning and control. Furthermore, it is suggested that managers perceive their environment to be highly uncertain may require more strategic cost management information to manage the uncertainty. Based on the above discussion, the following hypothesis will be tested in the research:

H 1: There is a positive association between PEU and Strategic cost management usage

\subsection{Structure}

According Chenhall (2003) organizational structure is about the formal specification of different roles for organizational members, or tasks for groups, to ensure that the activities of the organization are carried out For this research, 
structure has been conceptualised in terms of the centralisation/ decentralisation dimension (Chenhall \& Morris, 1986; Merchant, 1981). A decentralised structure distributes authority for decision making to a large number of lower level managers; whereas, a central ised structure focuses decision making authority at the headquarters level with few managers involved.

In the service context, organizational structure is likely to play a positive role in affecting the extent to which strategic cost management tools are used. It is suggested in this study, that firms which are more decentralised are likely to require a greater volume of information at lower levels of management to assist in decision making relative to central ised firms. Therefore, decentralised firms would have a greater need for SCM tools, as these provide additional information to help lower level managers in their decision-making processes. Therefore, it is hypothesised that:

H 2: There is a positive association between organizational structure and strategic cost management usage

\subsection{Organizational life cycle stage}

According to Miller and Friesen, (1984) a firm's life cycle stage is a contingency to which organizational responses have to be matched. This implies that the use of management accounting systems differs across the stages of organizational life cycle as different systems are needed in different stages (Kallunki \& Silvola, 2008). Additional research by Miller and Friesen (1984) show that firms in the maturity phase put significantly more emphasis on formal cost controls than firms in the growth stage. On the contrary, Auzair and Langfield-Smith (2005) used a self-categorization measure based on the firm's own assessment of its life cycle stage and reported that organizational life cycle, among other contingent variables, has a significant effect on the design of a firm's management accounting systems. Furthermore, Kallunki and Silvola (2008) found out that the organizational life cycle stage affects the use of innovative management accounting techniques, such as ABC.

Further findings by Chenhall and Langfield-Smith (1998) indicated that greater organizational size leads to greater complexity of tasks, which requires more division of labour. According to Chenhall and Langfield-Smith, (1998) more sophisticated integrative mechanisms such as information systems are then developed to coordinate the activities of subunits. "Management accounting innovations are examples of such information systems" (Kallunki \& Silvola, 2008). In addition, firms in the maturity stage as result of greater organizational size have greater resources to experiment with administrative innovations such as innovative management accounting tools (Kallunki \& Silvola, 2008). Kallunki and Silvola, (2008) report that greater organizational size and greater resources is expected to 
lead to more widespread use of strategic management accounting techniques among firms in the maturity stage as opposed to firms in the growth stage.

The above literature therefore indicates that there is a correlation between the organizational life cycle stage and the use of strategic cost management techniques. In the service context, the mature firms may have a more anal ysis of the competitor positions within the industries. This is because they use more cost data based on strategic and marketing information to develop and identify superior strategies so that may produce a sustainable competitive advantage. This is in order to analyse to a great extent of strategic factors in the pricing decision process in comparison with growth firms. In this case, the following hypothesis is tested:

H 3: There is a positive association between organizational life cycle stage and strategic cost management usage.

\subsection{Extent of the use of SCM and performance}

The relationship between management accounting usage and performance has been subjected to extensive empirical investigation (Chenhall \& Moers, 2007). According to 'contingency-based' research, a state of equilibrium in the relationship between the contingency factors and the type of MCS is best described by "fit" (Chenhall, 2003).

According to Cadez and Guilding (2008) "while most studies provide some support for the view that greater management accounting usage is positively associated with performance in many of these studies the relationship is inconclusive and context dependent" (see Cadez \& Guilding, 2008 for a review). While respecting these studies' mixed outcomes, Cadez and Guilding (2008) found that there is a positive association between SCM usage and performance.

This study proposes service firms that use more strategic cost management tools may enhance their performance relative to their competitors that use less strategic cost management practices. Thus, the following hypothesis is tested:

H 4: Greater SCM usage is positively associated with firm performance

\section{Research methodology}

\subsection{Sample characteristics and data collection}

In order to test the hypothesized relations among strategic management accounting techniques, contingent factors and performance, empirical data was collected from the Greek services industry. Greece economy is based on service sector (85\%) and industry (12\%), while the agricultural sector consists only $3 \%$ of the national economic output. The most important economic industries in Greece are tourism 
and merchant shipping. In fact, about 15 million international tourists visit Greece every year, which makes it the 7th most visited country in the EU and the 16th in the world. As for merchant shipping, Greece has the largest merchant marine in the world as it covers $16 \%$ of the world's total capacity.

We focused on sizable companies that would be likely to have an established management accounting function. The survey instrument was sent by email to 500 large Greek firms which are included in the ICAP database (Gall lup's subsidiary in Greece). The selection criteria used for sampling purposes were the sales revenues and the number of employees for year 2016. The collection of data lasted for four months, from February to May 2017. The questionnaire, accompanied by a cover letter where a brief reference to the scope of the study was made, was addressed to the Chief Financial Officers (CFO) of each firm It should be noted that the questionnaire was accompanied also by one glossary that explained the terminology of the strategic cost management tools adopted by Cadez and Guilding (2008).

Before starting the dissemination of the survey instrument, the questionnaire was pilot tested. Interviews were conducted with the Chief Financial Officers of 10 large firms. The pilot test did not reveal any shortcomings regarding either the content or the phrasing of the questions. Several procedures from Dillman (2000) were taken to optimize the response rate, such as the promise of strict anonymity, the use of high-quality printing with handwritten signatures, the use of pre-stamped envel opes and separate cards to request the study's results. A total of 88 firms fully completed and retumed the questionnaire, yielding a $18 \%$ response rate Companies that did not express interest in the research replied that the main reasons for not taking part in the survey were the lack of time and the fact that answering questionnaires was not one of their top priorities. The questionnaires were answered by Chief financial officers who have firm knowledge of the management accounting practices used within their companies and have the primary responsibility for product costing, planning and control decisions.

Tests for non-response bias were performed to determine (a) whether the distribution of the 500 organizations in the response $(n=88)$ or non-response ( $n=$ 232) categories was independent of available demographic characteristics and (b) whether early and late respondents provided significantly different responses. Chisquare tests indicated no significant differences in the demographic characteristics. Hotelling's $\mathrm{T}^{2}$ statistic al so indicated no significant differences in the multivariate means of early versus late respondents.

\subsection{Variable measurement}

The variable "Extent of use of strategic cost management techniques" was measured drawing on the scale by Cadez and Guilding (2008). It was slightly 
adapted to be understandable in services based on information from the interviews with six managers who specialize in management accounting. It comprises of a tenitem seven-point Likert-scal ed instrument anchored by (1) 'to no extent' to (7) 'to a great extent', in which respondents were asked to indicate the extent of the use of strategic cost management techniques.

The measurement of "Organizational life cycle stage" was based on the Kazanjian and Drazin (1990) self-categorization measure, with modifications as the original instrument was designed for technology-based ventures; this instrument was used by Auzair and Langfield-Smith (2005). The description offered at each stage of the life cycle by Kazanjian and Drazin was compared with Quinn and Cameron's (1983) summary of nine life cycle models. Consequently, three stages of organizational life cycle were measured: formation, growth and mature stages (Auzair and Langfield-Smith, 2005). Respondents were asked to select one box only that described their stage of development: formation (stagel), growth (stage 2) and maturity (stage 3). As only a few firms self-classified as stage 1 (2 firms), responses for stage 1 and stage 2 were combined into a single category, namely growth. Thus, only two stages were analysed - growth (35 firms) and maturity (53 firms) stages- which now resembles the dichotomous distinction used by Dodge et al. (1994) and by Auzair and Langfield-Smith (2005).

"Structure" was measured by the Gordon and Narayanan (1984), six-item seven point, Likert-scaled, fully-anchored instrument. Respondents were asked to strongly disagree (ranging 1) or strongly agree (ranging 7) with five statements regarding that the authority has been completely del egated to appropriate managers or employees to make decisions and one more statement which was: "The most operating decisions are made at l ower managerial level".

"Perceived environmental uncertainty" was measured by the Gordon and Narayanan (1984), point, Likert-scaled, fully-anchored instrument It was slightly adapted to be understandable in the hotel context Respondents were asked to strongly disagree or strongly agree with six statements regarding the perceived environmental uncertainty. These statements were (1) "The price competition in the industry is extremely intense", (2) "The economic external environment facing your firm changing rapidly", (3) "During the past 5 years many new services have been marked by industry", (4) "The market activities of your competitors during the past 5 years becoming less predictable", (5) "During the past 5 years, the tastes and preferences of your customers have become much harder to predict" and (6) "During the past 5 years, the legal, political and economic constraints surrounding your firm have proliferated greatly". Next to each statement, a seven-point scale was provided, ranging from " 1 " (strongly disagree) to " 7 " (strongly agree). 
"Performance" was measured using a slightly modified version by Cadez and Guilding (2008). It was slightly adapted to be understandable in a service context based on information from the interviews with six managers who specialize in management accounting. For each of these 6 dimensions, respondents were asked to indicate their firm's performance relative to their competitors on a scale ranging from " 1 " (below average) to "7" (above average). We included a number of control variables (strategy, size, age of the organization). Table 1 reports the descriptivestatistics of variables in the study.

T able 1. Descriptive statistics of the variables in the study

\begin{tabular}{|c|c|c|c|c|c|c|c|}
\hline Variable & $\mathbf{N}$ & M ean $D$ & $\begin{array}{c}\text { Std. } \\
\text { Deviation }\end{array}$ & $\begin{array}{l}\text { Theoretical } \\
\text { Minimum }\end{array}$ & $\begin{array}{l}\text { Theoretical } \\
\text { Maximum }\end{array}$ & $\begin{array}{c}\text { Actual } \\
\text { M inimum }\end{array}$ & $\begin{array}{c}\text { Actual } \\
\text { Maximum }\end{array}$ \\
\hline $\begin{array}{l}\text { Strategic cost management } \\
\text { usage }\end{array}$ & 88 & 4.24 & 0.58 & (1) & (1) & 1 & 7 \\
\hline $\begin{array}{l}\text { Organizational life cycle } \\
\text { stage }\end{array}$ & 88 & 0.58 & 0.51 & 0 & 1 & 0 & 1 \\
\hline $\begin{array}{l}\text { Perceived environmental } \\
\text { uncertainty }\end{array}$ & 88 & 4.44 & 0.68 & 1 & 7 & 1 & 7 \\
\hline Structure & 88 & 4.05 & 0.54 & 1 & 7 & 1 & 7 \\
\hline $\begin{array}{l}\text { Performance } \\
\text { Control variables }\end{array}$ & 88 & 4.09 & 0.48 & 1 & 7 & 2 & 7 \\
\hline Strategy & 88 & 4.91 & 0.89 & 1 & 7 & 1 & 7 \\
\hline Size (No of employees) & 88 & 285.11 & 24.81 & - & - & 85 & 625 \\
\hline Age of the organization & 88 & 34.12 & 16.14 & - & - & 1 & 51 \\
\hline Industry classification & $\mathrm{N}$ & $\%$ & & & & & \\
\hline Health care & 16 & 18 & & & & & \\
\hline Travel and leisure & 17 & 19 & & & & & \\
\hline Telecommunications & 8 & 9 & & & & & \\
\hline Banks & 4 & 5 & & & & & \\
\hline Insurance & 8 & 9 & & & & & \\
\hline Real estate & 6 & 7 & & & & & \\
\hline Financial services & 4 & 5 & & & & & \\
\hline Technology & 15 & 17 & & & & & \\
\hline Financial services & 7 & 8 & & & & & \\
\hline Other & 3 & 3 & & & & & \\
\hline Total & 88 & 100 & 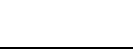 & 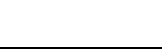 & 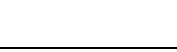 & & \\
\hline
\end{tabular}

"Organizational strategy" is based on Porter's classification scheme (Porter, 1980) and measured by the response to a single question drawn from Govindarajan (1988). This question asks the respondents to indicate their belief as to the best 
description of the business's strategic emphasis, ranging from cost leadership (ranging 1) to product differentiation (ranging 7).

"Size" was measured using the number of employees. The variable "Age of the organization" was measured by Kallunki and Silvola (2008). Respondents were asked to indicate the age of the firm in years since it was founded.

\section{Data analysis and results}

We test the research model using Partial Least Squares (PLS), a multivariate analysis technique for testing structural models (Chin, 1998). PLS is a general method for the estimation of path models involving latent constructs indirectly measured by multiple indicators (Chin \& Newsted, 1999). The measurement model in PLS is assessed in terms of individual item reliability, construct reliability and discriminant validity. Table 2 shows that the correlations between variables are generally low. The low correlations also suggest no problems exist with regard to multicollinearity (no correlation exceeds 0.30 in absolute value). Also, all VIF scores are below 2.5. The correlation between organizational life cycle stage and size is marginally significant, indicating that the organizational size of the firms is greater in maturity phase than it is in the growth phase which is consistent with prior research (Kallunki \& Silvola, 2008; Auzair \& Langfield-Smith, 2005). Table 3 shows the reliability and val idity statistics of multi-item constructs.

Table 2. C orrelations from PLS model $(n=88)$

\begin{tabular}{|c|c|c|c|c|c|c|c|c|}
\hline Variable & 1 & 2 & 3 & 4 & 5 & 6 & 7 & 8 \\
\hline $\begin{array}{l}\text { 1. Strategic Cost } \\
\text { Management usage }\end{array}$ & 1 & & & & & & & \\
\hline $\begin{array}{l}\text { 2. Perceived environmental } \\
\text { uncertainty }\end{array}$ & $0.214^{*}$ & 1 & & & & & & \\
\hline 3. Structure & $0.154^{*}$ & 0.082 & 1 & & & & & \\
\hline $\begin{array}{l}\text { 4. Organizational life cycle } \\
\text { stage }\end{array}$ & $0.208^{*}$ & 0.124 & 0.122 & 1 & & & & \\
\hline $\begin{array}{l}\text { 5. Strategy } \\
\text { 6. Size }\end{array}$ & $\begin{array}{l}0.192^{*} \\
0.125^{*}\end{array}$ & $\begin{array}{l}0.078 \\
0.104\end{array}$ & $\begin{array}{l}0.133 \\
0.132\end{array}$ & $\begin{array}{r}0.024 \\
0.101 *\end{array}$ & $\begin{array}{c}1 \\
0.205\end{array}$ & 1 & & \\
\hline 7.Age of the organization & 0.114 & 0.019 & 0.152 & 0.132 & 0.134 & 0.182 & 1 & \\
\hline 8. Performance & $0.285^{*}$ & 0.134 & 0.125 & 0.194 & 0.154 & 0.104 & 0.140 & 1 \\
\hline
\end{tabular}


Table 3. R eliability and validity analysis of multi-item constructs $(n=88)$

\begin{tabular}{|c|c|c|c|c|c|}
\hline Variable & ICR ${ }^{a}$ & Alphab & AVE $^{\mathrm{C}}$ & Item & L oading \\
\hline \multirow[t]{10}{*}{ Strategic Cost Management Usage } & \multirow[t]{10}{*}{0.855} & \multirow[t]{10}{*}{0.824} & \multirow[t]{10}{*}{0.644} & Benchmarking & 0.822 \\
\hline & & & & Competitor cost assessment & 0.824 \\
\hline & & & & $\begin{array}{l}\text { Competitive position } \\
\text { motoring }\end{array}$ & 0.788 \\
\hline & & & & $\begin{array}{l}\text { Competitor performance } \\
\text { appraisal }\end{array}$ & 0.781 \\
\hline & & & & $\begin{array}{l}\text { Customer profitability } \\
\text { analysis }\end{array}$ & 0.792 \\
\hline & & & & $\begin{array}{l}\text { Integrated performance } \\
\text { measurement }\end{array}$ & 0.801 \\
\hline & & & & Lifecycle costing & 0.789 \\
\hline & & & & Strategic pricing & 0.812 \\
\hline & & & & $\begin{array}{l}\text { Valuation of customers } \\
\text { as assets }\end{array}$ & 0.762 \\
\hline & & & & Value chain costing & 0.731 \\
\hline \multirow[t]{6}{*}{$\begin{array}{l}\text { Perceived environmental } \\
\text { uncertainty }\end{array}$} & \multirow[t]{6}{*}{0.815} & \multirow[t]{6}{*}{0.809} & \multirow[t]{6}{*}{0.687} & Price competition & 0.831 \\
\hline & & & & $\begin{array}{l}\text { Economic (external) } \\
\text { environment }\end{array}$ & 0.815 \\
\hline & & & & New services by industry & 0.764 \\
\hline & & & & $\begin{array}{l}\text { Market activities of } \\
\text { competitors }\end{array}$ & 0.779 \\
\hline & & & & $\begin{array}{l}\text { Tastes and preferences } \\
\text { of customers }\end{array}$ & 0.722 \\
\hline & & & & $\begin{array}{l}\text { Legal, political and economic } \\
\text { constraints surrounding fimm }\end{array}$ & 0.789 \\
\hline \multirow[t]{6}{*}{ Structure } & \multirow[t]{6}{*}{0.824} & \multirow[t]{6}{*}{0.809} & \multirow[t]{6}{*}{0.652} & $\begin{array}{l}\text { Initiating ideas for new } \\
\text { services }\end{array}$ & 0.806 \\
\hline & & & & $\begin{array}{l}\text { Hiring and firing managerial } \\
\text { personnel }\end{array}$ & 0.815 \\
\hline & & & & Budgeting allocations & 0.836 \\
\hline & & & & Pricing decisions & 0.787 \\
\hline & & & & Selecting large investments & 0.797 \\
\hline & & & & $\begin{array}{l}\text { Operating decisions are made } \\
\text { at manager level }\end{array}$ & 0.807 \\
\hline \multirow[t]{6}{*}{ Performance } & \multirow[t]{6}{*}{0.841} & \multirow[t]{6}{*}{0.814} & \multirow[t]{6}{*}{0.681} & Return on investment (ROI) & 0.811 \\
\hline & & & & Margin of sales & 0.801 \\
\hline & & & & Customer satisfaction & 0.872 \\
\hline & & & & Market share & 0.776 \\
\hline & & & & Service quality & 0.783 \\
\hline & & & & Development of new services & 0.824 \\
\hline
\end{tabular}

${ }^{\mathrm{a}}$ Internal composite reliability

${ }^{b}$ Cronbach's alpha

${ }^{c}$ A verage variance extracted 
Table 4. Extent of the use of strategic cost management techniques $(n=88)$

\begin{tabular}{lccccccc}
\hline \multicolumn{1}{c}{ Technique } & \multicolumn{7}{c}{ Actual Percentages (\%) } \\
\hline & 1 & 2 & 3 & 4 & 5 & 6 & 7 \\
\hline Benchmarking & 1 & 2 & 8 & 28 & 34 & 24 & 3 \\
$\begin{array}{l}\text { Competitor cost assessment } \\
\text { Competitive position }\end{array}$ & 6 & 10 & 22 & 25 & 21 & 15 & 1 \\
$\begin{array}{l}\text { motoring } \\
\text { Competitor performance }\end{array}$ & 2 & 6 & 18 & 30 & 24 & 16 & 4 \\
appraisal & 3 & 9 & 20 & 26 & 20 & 19 & 3 \\
$\begin{array}{l}\text { Customer profitability } \\
\text { analysis }\end{array}$ & 3 & 5 & 12 & 28 & 30 & 18 & 4 \\
Integrated performance & 4 & 9 & 17 & 24 & 23 & 17 & 6 \\
measurement & 6 & 10 & 23 & 24 & 20 & 14 & 3 \\
Life cycle costing & 4 & 5 & 16 & 33 & 23 & 16 & 3 \\
Strategic pricing & 5 & 10 & 20 & 23 & 20 & 17 & 5 \\
Valuation of customers as & 5 & 9 & 17 & 25 & 19 & 18 & 7 \\
assets & Value chain costing & 5 & & & & & \\
\hline NOTE: 7-point rating scale: 1: No extend; $7:$ great extent & & & & &
\end{tabular}

Table 4 shows the frequencies use of strategic cost management techniques. The figures in this table confirm that at the moment of the survey the majority of the firms in our sample use strategic cost management tools. The extents of the use of benchmarking and customer profitability analysis were somewhat more widespread that the other strategic cost management practices.

According to Hulland (1999), one consequence of the comparison between covariance structure analysis modelling approaches and PLS is that no proper overall goodness-of-fit measures exist for models using the latter. The structural model is evaluated examining the $R^{2}$ values and the size of the structural path coefficients. Consistent with Chin (1998), bootstrapping based on 500 runs is used to generate standard errors and t-statistics. This allows us to assess the statistical significance of the path coefficients.

Table 5 reports the path coefficients, t-values observed with the leve of significance achieved and the proportion of explained variance of the endogenous variable $\left(R^{2}\right)$ for the whole sample $(n=88)$. 
Table 5. Results from PL S analysis $(n=88)$

\begin{tabular}{lcc}
\multicolumn{1}{c}{ Path to: } & SCM usage & Performance \\
\hline Path from & Path coefficient & $\begin{array}{c}\text { Path } \\
\text { coefficient }\end{array}$ \\
\hline Perceived environmental uncertainty & $0.244^{*}$ & \\
& $(2.403)$ & \\
Structure & $0.188^{*}$ & \\
& $(2.132)$ & \\
Organizational life cycle stage & $0.189^{*}$ & \\
& $(2.012)$ & \\
SCM usage & & $0.324^{*}$ \\
Control variables & & $(2.599)$ \\
Strategy & $0.233^{*}$ & \\
& $(2.235)$ & $(0.162$ \\
Size & $0.192^{*}$ & 0.175 \\
& $(2.019)$ & $(0.184)$ \\
Age of the organization & 0.154 & 0.164 \\
& $(0.148)$ & $(0.178)$ \\
NOTE: * indicates Correlations is significant at the .05level (2 tailed) & $\mathrm{R}^{2}=0.214$ & $\mathrm{R}^{2}=0.234$ \\
\hline
\end{tabular}

Regarding perceived environmental uncertainty, there is strong support for $\mathrm{H} 1$, as expected. The results show that perceived environmental uncertainty $(\beta=0.244 p<$ 0.05 ) has a significantly positive effect on the use of strategic cost management techniques. The results support $\mathrm{H} 2$, since the path coefficient from structure to SCM use is positive and significant $(\beta=0.188, p<0.05)$. Moreover, the results support $\mathrm{H} 3$, since the path from organizational life stage on the use of strategic cost management tools is positive and significant ( $\beta=0.189, p<0.05)$. The data analysis shows that the use of strategic cost management is greater among firms in maturity phase than among firms in a growth phase. Consistent with expectations, strategy $(\beta=0.233, p<0.05)$ and size $(\beta=0.192, p<0.05)$, which I add as control variables, are positively and significantly associated with SCM usage. On this note, firms following a differentiation strategy use more SCM than firms following a cost leadership strategy.

With respect to the relationship between SCM and performance, SCM use exhibits a statistically significant positive relationship $(\beta=0.324, p<0.05)$, so there is a strong support of $\mathrm{H} 4$. The results of the structural model show that contingent factors, such as PEU, structure, organizational life cycle stage, strategy and size do not directly related to performance. 


\section{Conclusion and discussion}

This study focuses on the organizational framework of strategic cost management (Cadez \& Guilding, 2008). The anal ysis of the survey data obtained from $88 \mathrm{Greek}$ service firms indicates that the use of strategic cost management techniques can be considered quite satisfactory. According to the survey, the use of benchmarking and customer profitability analysis is much more widespread than other strategic cost management practices including life cycle costing, strategic pricing, competitive position motoring, competitor cost assessment, competitor performance appraisal, integrated performance measurement, valuation of customers as assets and value chain costing.

The findings provide support for contingency theory's central proposition that firm performance depends on the fit between organizational context and structure. The survey revealed that SCM usage is positively affected by these five contingent factors (PEU, Structure, organizational life cycle stage, strategy size). while SCM usage, in turn, positively affects performance. A significant mediating effect of SMA usage on performance is evident. The findings emanating from the PLS model provide support for all the hypothesized relationships. The survey results provide support for the application of contingency theory in management control system design in services. The extent of the use of SCM is not necessarily related to superior firm performance, but that superior firm performance is a product of an appropriate match between contingent factors and SCM usage. Thus, the results support the argument that performance is related to its choice of strategic cost management practices. The extent of the use of SCM tools, in turn, also positively affects performance Given that in a PLS model fit is depicted as a statistically significant (Gerdin \& Greve, 2004); these results provide support to contingency theory.

However, the findings presented in this paper are subject to a number of limitations. Some of these limitations are inherent to the survey method used such as the use of perceptual measures and the potential of common-method bias. By closely following the guidelines of Dillman (2000) however, we have tried to limit these limitations as much as possible. We have also used more objective data where possible.

The study has helped in adding to the knowledge in management accounting practices in services. The results provide the first empi rical evidence of the relation between the use of strategic cost management techniques, organizational factors and performance in service organizations.

This study extends prior research in several ways. Firstly, it has provided additional insights into areas relating to factors influencing the use of SCM. More 
specifically, the constructs perceived environmental uncertainty, structure and organizational life cycle stage are introduced as factors that influence the use of strategic cost management practices. Secondly, this paper adds to the limited body of knowledge of the design of MAS in a service context (service management accounting system design). While most of the previous research has focused on SMA in manufacturing firms, this study focuses on a service context and contributes to the meager knowledge that we have about contextual variables that influence the design of SMA systems in service industries.

The study can also be seen as constituting an enquiry into the validity of viewing strategic cost management as an empirical construct in a service environment. Finally, the results provide insights potentially useful for accounting practitioners, academics, and owners of service firms to design strategic cost management systems that " $\mathrm{fit}$ " with their contextual factors in order to enhance performance.

Future research should consider incorporating other important variables that have been omitted from other studies and are likely to influence the use of SCM. The most notable omitted variables are organizational variables, such as technology, TQM and organizational culture (Chenhall, 2003; Abernety \& Bouwens, 2005). Moreover, the SCM systems of service firms could be studied in depth in order to examine the perceived benefits and useful ness that arise from their implementation. Finally, should be investigated whether the heterogeneity of the sample (different sub - industries) affects the results.

\section{R eferences}

Abdel-Kader, M. \& Luther, R. (2008) "The impact of firm characteristics on management accounting practices: A UK-based empirical analysis", The British Accounting Review, vol. 40: 2-27.

A bernethy, M. A. \& Bouwens, J. (2005) "Determinants of accounting innovation implementation", Abacus, vol. 41: 217-240.

A bernethy, M.A. \& Brownell, P. (1999) "The role of budgets in organizations facing strategic change: an exploratory study", Accounting Organization and Society, vol. 24: 189-204.

Anderson, S.W. \& Lanen,W.N. (1999) "Economic transition, strategy and the evolution of management accounting practices: the case of India", Accounting Organization and Society, vol. 24: 379-412.

Auzair, S. (2015) "A configuration approach to management control systems design in service organizations", J ournal of Accounting \& Organizational Change, vol. 11: 47-72.

Auzer, S. \& Langfield-Smith, K. (2005) "The effect of service process type, business strategy and life cycle stage on bureaucratic MCS in service organizations", Management Accounting Research, ol. 2: 227-248. 
Bromwich, M. (1990) "The case for strategic management accounting: The role of accounting information for strategy in competitive market", Accounting, Organizations and Society, vol. 15: 27-46.

Cadez, S. \& Guliding, C. (2008) "An exploratory investigation of an integrated contingency model of strategic management accounting", Accounting Organization Society, vol. 33: 836-863.

Carr, C. \& Tomkins, C. (1996), "Strategic investment decisions: the importance of SCM. A comparative analysis of 51 case studies in U.K., U.S. and German companies", Management Accounting Research, vol. 7: 199-217.

Carr, C. \& Tomkins, C. (1998), "Context, culture and the role of the finance function in strategic decisions. A comparative analysis of Britain, Germany, theU.S.A. and J apan", Management Accounting Research, vol. 9: 213-239.

Carr, C., Tomkins, C. \& Bayliss, B. (1991) "Strategic controllership - a case study approach", Management Accounting Research, vol. 2: 89-107.

Chenhall, R. (2003) "Management controls systems design within its organizational context: Findings from contingency-based research and directions for the future", Accounting, Organizations and Society, vol. 28: 127-168.

Chenhall, R.H. \& Langfield-Smith, K., (1998) “The relationship between strategic priorities, management techniques and management accounting: an empirical investigation using a systems approach", Accounting Organization Society, vol. 23Q 243-264.

Chenhall, R. \& Morris, D. (1986) "The impact of structure, environment, and interdependence on the perceived useful ness of management accounting systems", The Accounting Review, LXI: 16-35.

Chenhall, R. H., \& Moers, F. (2007) "The issue of endogeneity within theorybased, quantitative management accounting research", European Accounting Review, vol.16: 173-195.

Chenhall, R., \& Moers, F., (2015) "The role of innovation in the evolution of management accounting and its integration into management control" Accounting, Organization and Society, vol. 47:1-13

Chin, W. W. \& Newsted, P. R. (1999). Structural equation modeling analysis with small samples using Partial Least Squares, in: R. Hoyle (Ed.) Statistical Strategies for Small Sample Research, pp. 307-341, Thousand Oaks, CA: Sage.

Chin, W. (1998) "Issues and opinion on structural equation modelling", MIS Quarterly, March: vii-xvi.

Cinquini, L. \& Andrea Tenucci. A. (2010) "Strategic management accounting and business strategy: a loose coupling', Journal of Accounting \& Organizational Change, vol. 6: 228-259.

Cravens, K. S. \& Guilding, C. (2001) "An empirical study of the application of strategic management accounting techniques" Advances in Management Accounting, vol. 10: 95-124. 
Dillman, D. (2000). Mail and Internet surveys: The Tailored Design Method, New York: Wiley.

Gerdin, J. \& Greve, J. (2004) "Forms of contingency fit in management accounting research - A critical review", Accounting, Organizations and Society, vol. 29: 303-326.

Gordon, L. \& Narayanan, V. (1984) “Management accounting systems, perceived environmental uncertainty and organization structure: an empirical investigation", Accounting, Organization and Society, vol. 9: 33-47.

Govindarajan, V. (1988), "A contingency approach to strategy implementation at the business level: integrating administrative mechanisms with strategy", Academy of Management J ournal, vol.31: 828-853.

Guilding, C., and McManus, L. (2002) "The incidence, perceived merit and antecedents of customer accounting: an exploratory note", Accounting, Organizations and Society, vol. 27: 45-59.

Guilding, C. Cravens, K. S. \& Tayles, M. (2000) "An international comparison of strategic management accounting practices" Management Accounting Research, vol. 1: 113-135.

Gul, F. \& Chia, Y. (1994) "The effect of management accounting systems, perceived environmental uncertainty and decentralization on managerial performance: a test of three-way interaction, Accounting, Organization and Society, vol. 19: 413-426.

Hulland, J. (1999) "Use of Partial Least Squares (PLS) in strategic management research: a review of four recent studies", Strategic Management J ournal, vol. 20: 195-204.

Kallunki, J. \& Silvola, A. (2008),"The effect of organizational life cycle stage on the use of activity-based costing", Management Accounting Research, vol. 19: 62-79.

Kazanjian, R.K. \& Drazin, R. (1990) "A stage-contingent model of design and growth for technology-based new ventures", J. Business Venturing, vol. 5: 137-150.

Lawrence, P. \& Lorsch, J. (1967). Organization and Environment Irwin, Homewood, IL.

Merchant, K.A. (1981) "The design of corporate budgeting system: influences on managerial behaviour and performance", Accounting Review, vol. 56: 813-829.

Messner, M. (2016) "Does industry matter? How industry context shapes management accounting practice", Management Accounting Research, vol. 31: 103-111.

Miller, D. \& Friesen, P.H. (1984) "A longitudinal study of the corporate life cycle", Management Science, vol. 30: 1161-1183.

Naranjo-Gil, D., Maas, V. \& Hartmann, F. (2009) "How CFOs determine management accounting innovation: an examination of direct and indirect effects", European Accounting Review, 1 vol. 8: 667-695. 
Otley, D. (2016) "The contingency theory of management accounting and control: 1980-2014", Management Accounting Research, vol. 31:45-62.

Porter, M. (1980). Competitive Strategy. The Free Press, New Y ork.

Quinn, R. \& Cameron, K., 1983 “Organizational life cycles and shifting criteria of effectiveness: some preliminary evidence", Management Science, vol. 29: 33-51.

Pavlatos, O. (2015) "An empirical investigation of strategic management accounting in hotels", International J ournal of Contemporary Hospitality Management, vol. 27: 756-767.

Roslender, R. \& Hart, S. (2003) "In search of strategic management accounting: Theoretical and field study perspectives", Management Accounting Research, vol. 1: 255-279.

Simmonds, (1981). The Fundamentals of Strategic Management Accounting. CIMA.

Simons, R. (1987) "Accounting control systems and business strategy" Accounting, Organizations and Society, vol. 12: 357-374.

Tillmann, K. \& Goddard, A. (2008) "Strategic management accounting and sense making in a multinational company", Management Accounting Research, vol. 19: 80-102.

Zawawi, N. \& Hoque, Z. (2010) "Research in management accounting innovations: An overview of its recent development", Qual itative Research in Accounting \& Management, vol. 7:505-568. 